\title{
Innovative Tools and Techniques as a Factor Supporting Small and Medium Enterprises in the Agri-Food Sector ${ }^{3}$
}

\begin{abstract}
The goal of the paper was to focus on the agri-food sector from a perspective of innovation. In the article, the current situation related to innovative tools and techniques identified in the agri-food sector was presented. The attention was focused on the benefits resulting from the application of innovative solutions in three areas: food safety, mechatronics, and packaging design. The empirical part of the paper includes a description and a summary of case studies on innovations implementations conducted within the framework of the Interreg I-CON project.
\end{abstract}

Key words: agri-food sector, innovations, quality management, mechatronics, packaging design

JEL Classification:O13, O52, Q12, Q16

\section{Introduction}

Over the last two decades, the agri-food sector, which is one of the most critical areas of the Polish economy, has undergone significant changes, and one of the incentives was Poland's accession to the European Union. It also concerns other countries, like Slovenia, Hungary, and Slovakia. Companies face the necessity of constant adaptation to the changing conditions of functioning on the market, which result to a large extent from changes in customer preferences and requirements. For the agri-food industry, it is not only the current state that is important but also the vision of development and prognosis for the future (Kiełbasa, 2015). In order to stay on the market, enterprises from the food sector have to continually develop and look for new solutions, which can be implemented both thanks to constant investments and the introduction of new technologies and thanks to the support from other entities.

This underlines the need to take action to stimulate economic activity with the potential to create jobs for regions encountering difficulties in supporting economic development. The agri-food sector is one of the most important, potential fields for improving the socio-economic situation. One way is indeed to improve entrepreneurial competencies and skills through innovative potential. In the globalized food market for small and medium-sized enterprises, innovation is also an essential strategic tool for gaining a competitive advantage (Avermaete and Viaene, 2002; Kühne et al., 2010). They determine the pace and directions of development, and they are a factor of national and international competition (Wasilewski et al., 2010).

\footnotetext{
${ }^{1} \mathrm{dr}$ hab., Faculty of Applied Informatics and Mathematics, 159, Nowoursynowska Street, 02-776 Warsaw, e-mail: sebastian_jarzebowski@sggw.pl; https://orcid.org/0000-0002-9394-577X

${ }^{2}$ MSc, e-mail: natalia.bezat@gmail.com

3 The paper was prepared within the research granted within Interreg CE Programme as a project no CE393 „Improving COmpetences and skills through Food sector InNovations - I-CON”.
} 
The forerunner of innovation research - Schumpeter - believed that innovation is the introduction of new products, new production methods, finding new markets, gaining new sources of raw materials and introducing a new organization (Schumpeter, 1960). According to Brewin (Brewi et al., 2009), innovations are understood as new products, new processes, new markets, and new organizational methods. The fundamental factors affecting the introduction of innovations by enterprises include:

- material, capital and human resources possessed by the company, accumulated experience, and skills ensuring the ability to adopt innovations and gain a competitive advantage in the market,

- market and institutional conditions that create a climate of competitiveness, combined with the active role of the state,

- entrepreneurship culture and education systems (Dobiegała-Korona, 1996).

Food innovations are mainly related to process innovations, such as packaging innovations and changes in product composition, product size and product use (Gellynck and Kühne, 2008). Numerous crises related to food safety aroused great concern among consumers, and as a result of these crises, they contributed to raising consumer awareness. As a result, the food industry was faced with the challenge of providing consumers with safe products with the required sensory characteristics at an affordable price. Food safety is significant public health and economic issue in Europe for both foods consumed in the EU and exported products. Therefore, the agri-food sector faces challenges such as:

- anticipating and monitoring of the known and emerging biological and chemical threats,

- proper assessment of benefits and communication with entities in the food chain,

- understanding and solving consumer problems related to food safety.

Technological progress provides new tools and opportunities to address the challenges mentioned above. One of the measurements of the effectiveness of the quality management system consists in monitoring customer satisfaction with the product or service. As food safety has become a priority, food producers are committed to communicating food safety to consumers (Röhr et al., 2005). An important aspect is the management of hazards and risks related to the processing, distribution and sale of food - from monitoring information on specific hazards (e.g. known and emerging pathogens, allergens, foreign bodies, etc.) by continually seeking food safety to implement in practice such systems as HACCP (Hazard Analysis Critical Control Points) and TACCP (Threat Analysis and Critical Control Points).

Another aspect is the packaging design. Companies operating in the food industry indicate packaging as an essential and integral part of their products. However, the focus on maintaining low packaging costs is noticeable.

In the next part of the paper, description and summary of case studies on innovations implementations conducted within the framework of the Interreg I-CON project were included. The primary objective of the project is to improve entrepreneurial competencies and skills in remote areas through food innovation potentials. Within the framework of the project existing knowledge was used to elevate bringing in new ideas, tools, and techniques to provide links of SMEs and competent actors of supporting innovation environment for faster development.

The method of case studies used in the project was recognized as the most appropriate for this kind of research. Case study research, through reports of past studies, allows the exploration and understanding of complex issues. It can be considered a robust research 
method particularly when a holistic, in-depth investigation is required. By including both quantitative and qualitative data, case study helps explain both the process and outcome of a phenomenon through complete observation, reconstruction, and analysis of the cases under investigation (Tellis and Winston, 1997). As an alternative to quantitative or qualitative research, case studies can be a practical solution when a significant sample population is difficult to obtain.

\section{Summarizing of qualitative research}

Increasing the competencies and skills of entities related to the food sector is an essential aspect of improving competitiveness on the European market. The entities that may be interested in introducing innovations are, above all, small and medium enterprises as well as relevant ministries, private and public research and development departments, chambers, clusters, innovation centers, and large enterprises.

The innovations were implemented by using service providers identified within the framework of the research. The map shows the geographical positioning of food service providers in the field of food safety mechatronics and packaging design (Fig 1). This tool supports enterprises enabling finding a suitable service provider using various criteria (country, sector, type organization, scope of services provided). The numbers in circles represent the numbers of food technology, food design and food safety providers in a given country or region. Visual presentation of data can facilitate planning and strategic action for the implementation of innovation in the EU.

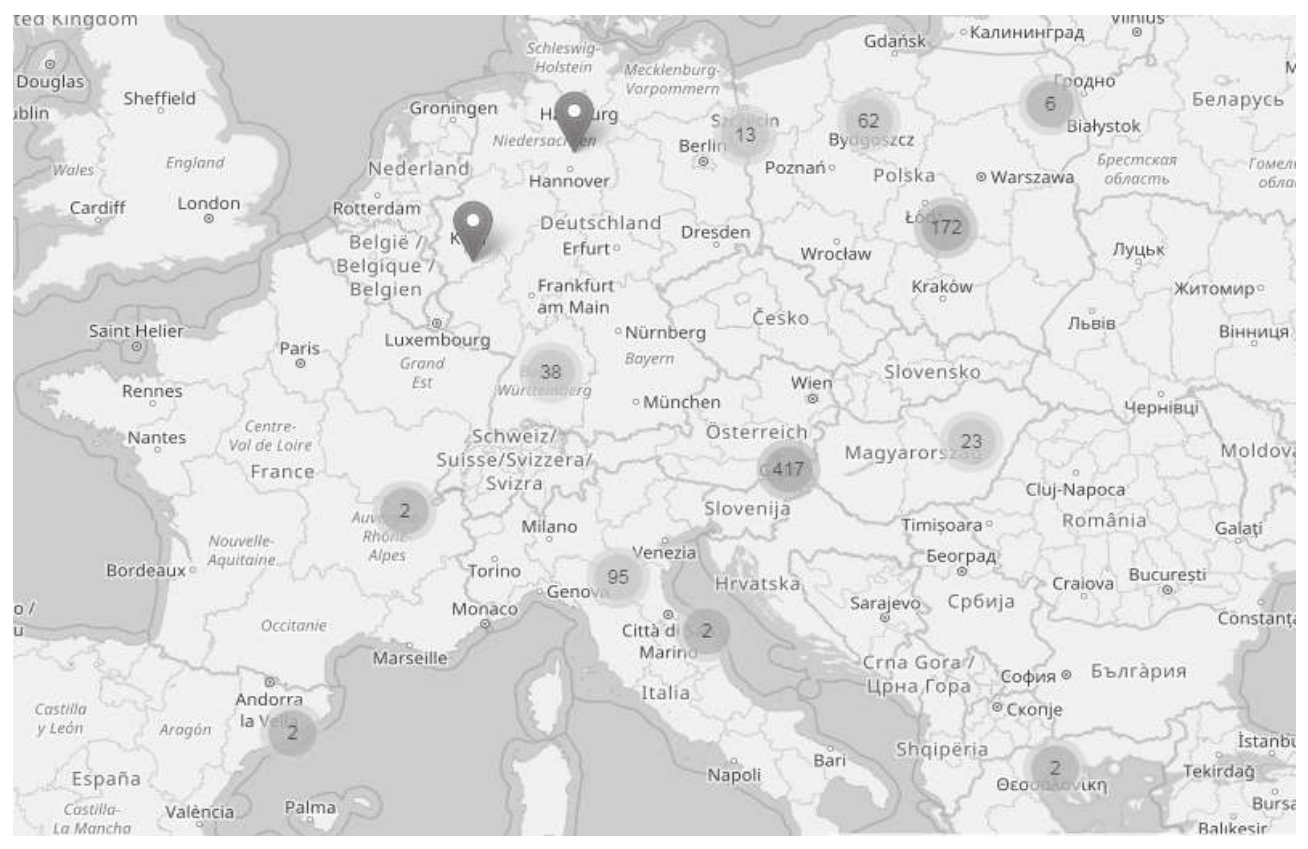

Fig. 1. A map of food technology, food design and food safety providers (2017)

Source: own work based on the results of the I-CON Project. 
In order to investigate innovations implemented by entities related to the food sector, examples from eight European Union countries (Slovenia, Austria, Hungary, Italy, Germany, Poland, Slovakia, Belgium) were analyzed in the area of:

- food safety, quality and labeling (49 examples),

- mechatronics (11 examples),

- $\quad$ packaging design (9 examples).

For this group of enterprises, added values resulting from the application of individual innovations were identified. The collected innovative tools and techniques have several novelties, benefits and added values which can improve the competitiveness of the food businesses, especially the SMEs' performance and success on the market.

The benefits enabling enterprises to increase their competitiveness on the market include improvement of cost-effectiveness, improvement of product quality, improvement of risk management, compliance with legal regulations, product assessment, information provided to users and user satisfaction (see Fig. 2). Other benefits were also identified, such as food protection, waste reduction, reduction of harmful substances emissions, effective use of natural resources, protection of intellectual property.

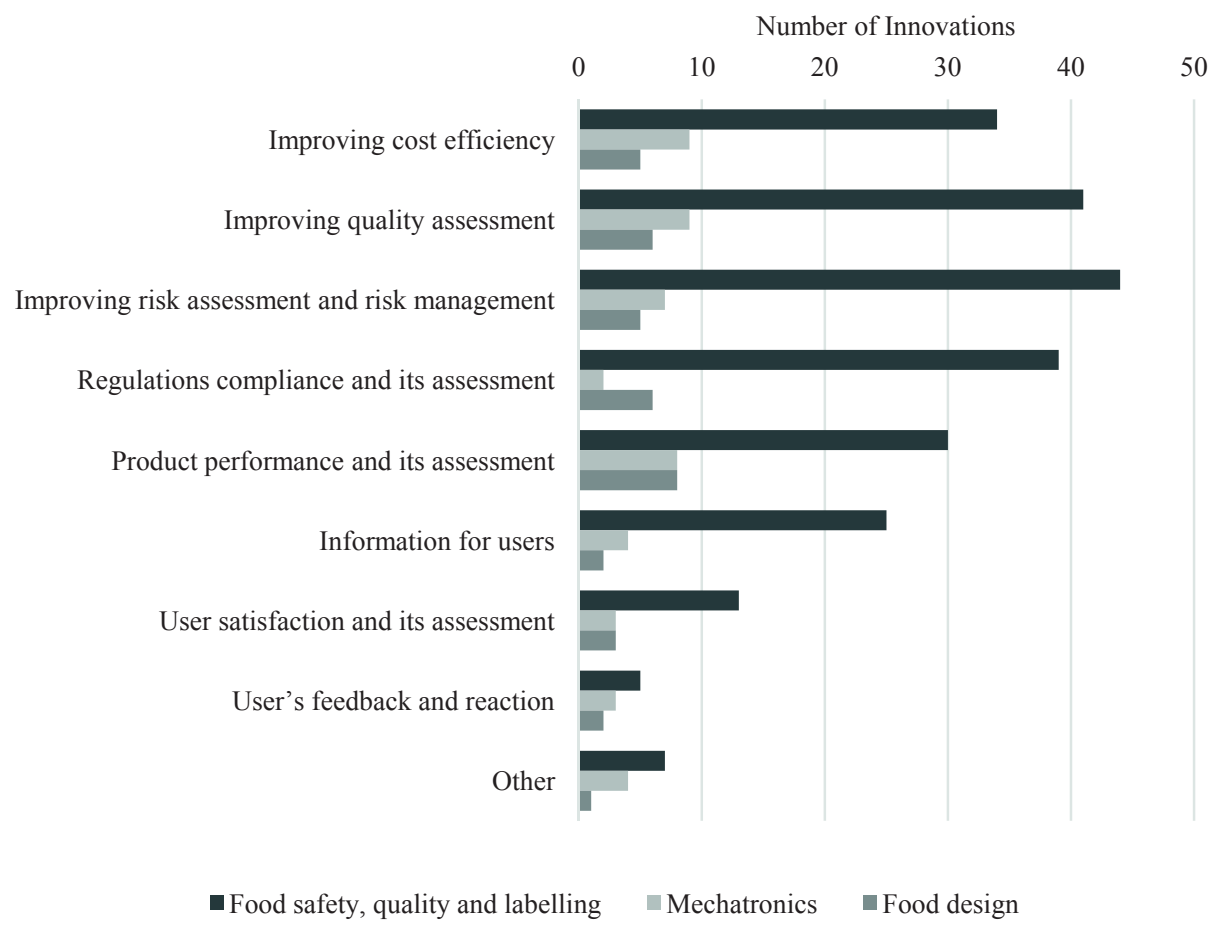

Fig. 2. The division of innovations depending on the benefits achieved and the area of implementation (2017)

Source: own work based on the results of the I-CON Project.

The most identified innovations were in the form of guidelines and recommendations (21 examples) and descriptions of the technologies and methods used (23 examples). Other 
examples of innovations were the description of equipment or training, the characteristics of the expert group and the specification of databases (Fig 2).

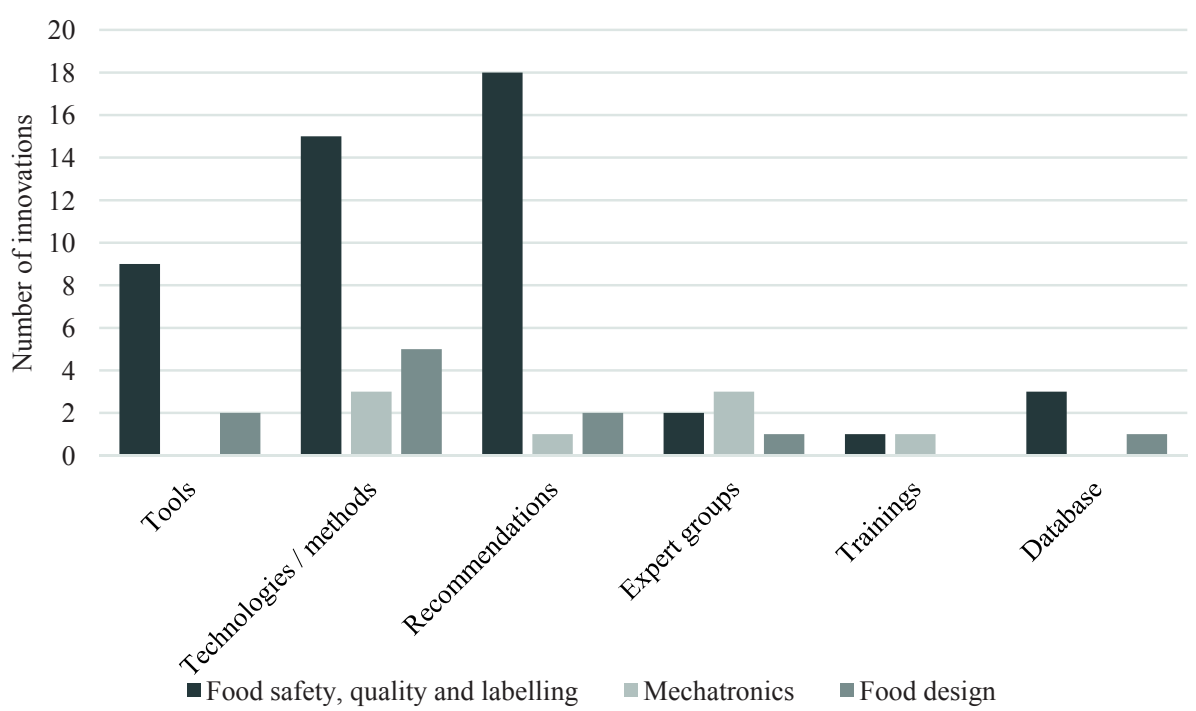

Fig. 3. The division of innovations depending on the type the area of implementation (2017)

Source: own work based on the results of the I-CON Project.

One of the practices analyzed in the project is the innovation concerning antitampering smart labels, which was proposed by the Finnish institute VTT Technical Research Center of Finland Ltd. The possibilities of paper electronics reduce the likelihood of interference in the content of the packaging and to detect them effectively.

Food tampering involves the deliberate altering or adulteration the product or its package. Tampering attempts may be made at any phases of distribution, logistics or sale. Modes include Economically Motivated Adulteration (to gain an increased income from selling a foodstuff in a way which deceives customers and consumers) and Tampering (when a malicious person alters or interferes with a food item and introduces a food safety agent).

Packaging primarily serves to protect the food from contamination, loss of volatile components and other environmental factors (e.g., oxygen or light). For pre-packaged foods, the legislation also demands the packaging to provide additional integrity to the food item in a way that the contents cannot be altered without opening or changing the packaging. Extending this principle to food raw materials and additives is the common interest of both the manufacturer and the user to maintain full food safety by ensuring that the packaging provides adequate protection but also reliable ways to detect if the integrity has been compromised.

The benefits of using smart labels appear in many areas (Table 1). First and foremost, customers receive full information about the product and can check whether any interference has occurred in the contents of the packaging. Additionally, the risk related to food safety is significantly reduced, and the quality of the product increases. 
Table 1. Benefits of smart labels

Table 1. Benefits of smart labels

\begin{tabular}{l|c}
\hline \multicolumn{1}{c|}{ Areas of novelties and benefits } & Impact \\
\hline Improving cost efficiency & none \\
Improving quality assessment & none \\
Improving risk assessment and risk management & positive \\
Regulations compliance and its assessment & positive \\
Product performance and its assessment & positive \\
Information for users & positive \\
User satisfaction and its assessment & positive \\
User's feedback and reaction & none \\
Other & increased food safety \\
\hline
\end{tabular}

Source: own work based on the results of the I-CON Project.

When used within a supplier partnership, smart labels permit automatic processing of hundreds of incoming items per hour individually reporting their status and condition on the push of a button or through a radio interface. Supplier and user will have the capability to accurately and unanimously identify the product and its unopened status. The printing technology developed by VTT allows cheap, mass manufacture of smart labels with a human or machine readable interface.

\section{Summary and Conclusions}

In the paper, the main focus was put on the agri-food sector from a perspective of innovation. In order to investigate innovations implemented by entities related to the food sector, examples from eight European Union countries (Slovenia, Austria, Hungary, Italy, Germany, Poland, Slovakia, Belgium) were analyzed. Three groups of innovation were in focus in the paper, namely food safety, quality and labeling, mechatronic and packaging design.

The benefits resulting from the application of innovative solutions in this three areas were identified. They include the benefits enabling enterprises to increase their competitiveness on the market include improvement of cost-effectiveness, improvement of product quality, improvement of risk management, compliance with legal regulations, product assessment, information provided to users and user satisfaction. Other benefits were also identified, such as food protection, waste reduction, reduction of harmful substances emissions, effective use of natural resources, protection of intellectual property.

\section{References}

Avermaete, T., Viaene, J. (2002). On Innovation and Meeting Regulation - the Case of the Belgian Food Industry. DRUID Summer Conference on "Industrial Dynamics of the New and Old Economy - who is embracing whom?".

Brewi, D.G., Monchuk, D.C., Partridge, M.D. (2009). Examining the Adoption of Product and Process 
Innovations in the Canadian Food Processing Industry. Canadian Journal of Agricultural Economics, 57(1), 75-97.

Dobiegała-Korona, B. (1996). Strategia rozwoju Polski a innowacyjność. Gospodarka Narodowa, 5, 12-16.

Gellynck, X., Kühne, B. (2008). Innovation and collaboration in traditional food chain networks. Journal on Chain and Network Science, 8(2), 121-129.

Kiełbasa, M. (2015). Przyszłość sektora rolno-spożywczego w Polsce w odniesieniu do stanu obecnego. Progress in Economic Sciences, 2, 228.

Kühne, B., Vanhonacker, F., Gellynck, X., Verbeke, W. (2010). Innovation in traditional food products in Europe: Do sector innovation activities match consumers' acceptance? Food Quality and Preference, 21(6), 629638.

Röhr, A., Lüddecke, K., Drusch, S., Müller, M.J., Alvensleben, R.V. (2005). Food quality and safety-consumer perception and public health concern. Food Control, 16(8), 649-655.

Schumpeter, J. (1960). Teoria rozwoju gospodarczego. PWN, Warszawa.

Tellis, W.M. (1997). Introduction to Case Study. The Qualitative Report, Volume 3, Number 2, July. (http://www.nova.edu/ssss/QR/QR3-2/tellis1.html).

Wasilewski, M., Wasilewska, A., Bezat, A. (2010). Innowacyjność przedsiębiorstw przetwórstwa rolnospożywczego: stan wiedzy i kierunki dalszych badań. Zeszyty Naukowe SGGW Ekonomika i Organizacja Gospodarki Żywnościowej, 82, 103-114.

\section{For citation:}

Jarzębowski S., Bezat N. (2018). Innovative Tools and Techniques as a Factor Supporting Small and Medium Enterprises in the Agri-Food Sector. Problems of World Agriculture, 18(4), 192-198; DOI: 10.22630/PRS.2018.18.4.110 